\title{
Kurgusal Mekanlarda Akıllı Teknolojilerin, Bilim Kurgu Filmlerinin İç Mekan İncelenmesi
}

\author{
I. Emre KAVUT ${ }^{1}$
}

\section{Öz}

Teknolojik gelişmelerin her geçen gün yeni fikirler ve olanaklar sağlaması günlük yaşantımıza da yansımaktadır. Bir tasarım fikri veya öngörü olarak ortaya çıkan bu gelişmelerin yaşantımıza entegrasyonuna öncülük eden en önemli dallardan biri de sinemadır. Teknolojinin sinemada yer almasıyla birlikte bilim kurgu filmleri ortaya çıkmıştır. Bilim kurgu filmleri geleceği anlatırken, mimari mekanlara da farklı bakış açıları için ilham kaynağı olmuştur. Bu çalışmada geleceği anlatan bilim kurgu filmleri üzerinden teknolojik gelişmelerin iç mekanlardaki akıllı teknolojiler kapsamında verdiği fikirlerin günümüz teknolojilerine ne kadar yansıdığı tespit edilecektir. Bu bağlamda incelenecek olan filmlerde iç mekanlarda kullanılan akıllı teknolojilerdeki yenilikler irdelenecektir.

Anahtar Sözcükler: Akılı Teknolojiler, Bilim Kurgu, Sinema, Mimarlık

\section{Smart Technologies in Fictive Spaces, Interior Arcitecture Oriented Analysis of Sci-Fi Cinema}

\begin{abstract}
New ideas and opportunities provided by technological developments are reflected in our daily life day by day. One of the most important branches leading to the integration of these developments, which appears as a design idea or foresight in our lives is cinema. With inclusion of technology in cinema, Science fiction films started to be existed. While science fiction films tell the future, they have inspired the architectural spaces for different perspectives. In this study, it will be determined how the reflections of technological developments through smart technologies in interior spaces are reflected in today's technologies. In this context, innovations in the smart technologies used in interior spaces will be discussed.
\end{abstract}

Keywords: Smart Technologies, Science Fiction, Cinema, Architecture

\section{GiRiş}

Günümüzde yedinci sanat dalı olarak kabul edilen sinema 1895 yılında Lumiere Kardeşler'in icat ettiği cinematographe ile çekmiş oldukları filmlerde günlük hayattan kesitleri oldukları gibi aktarmalarıyla ortaya çıktı. Bu filmlerde mevcut olan aktarılırken bir tasarlama kaygısı söz konusu değildi. Fakat, zamanla mevcut olanı aynen aktarmanın yanı sıra, mevcut olanın dışındakilerin de aktarımı söz konusu olunca tasarım kaygısı oluşmaya başladı. (Şenyapılı, 2002)

Şenyapılı'nın da söylemlerinden yola çıkarak sinemada olanı belgelemekten öteye

\footnotetext{
${ }^{1}$ Mimar Sinan Üniversitesi İç Mimarlık Bölümü

* İlgili yazar/Corresponding author: emre.kavut@msgsu.edu.tr

Gönderim Tarihi / Received Date: 01.10.2019

Kabul Tarihi / Accepted Date: 08.06.2020
} 
gidilerek kurgulama kaygısının ortaya çıkması ve bununla birlikte tasarım kaygısının sinemada yer almasıyla mevcut konular dışında yeni konular da ele alınmaya başlandı. Böylece mimarlık ve sinemanın, tasarım kaygısı güden iki alan olmaları sebebiyle aralarındaki etkileşimin arttığını söyleyebiliriz.

Mimarlık ve sinemanın ortak özelliklerinden ilki tasarımdır. Hem mimarlık hem de sinema tasarlananı uygulama süreci içerisinde bazen benzer bazen de farklı yöntemler kullanarak gerçekliğe dönüştürmektedir. Güntan, mimarlığın iki boyutlu tasarımları, üç boyutlu gerçekliğe aktarırken, sinemanın ise üç boyutlu gerçeklikten yakaladığı görüntüleri film ortamına dönüştürüp, iki boyutlu ekranda gösterdiğini söylemiştir (Güntan, 2007).

Beşışık'a göre sinema bize hiç gitmediğimiz ve görmediğimiz yerleri deneyimleme fırsatı sunar, bu yönüyle mimari kültürel birikime ve eğitime katkıda bulunur ayrıca mekânsal deneyim zenginliği yaratır. (Beşışık,2013, s. 13). Mekân, sinema ve mimarinin etkileşimi söz konusu olduğunda ortak bir kavram olarak karşımıza çıkar. Sinemada mekân Tanyeli'ye göre; ya gerçekte var olmakta, ya bu gerçeklik içinde yeniden inşa edilmekte ya da sanal olarak tasarlanmaktadır (Tanyeli, 2001). Mimarlık tarihçisi Nikolaus Pevsner (1963)'in ise mimarlığı 'mekân yaratma' eylemi olarak ifade etmektedir.

Mekânın, mimarlık-sinema arakesitinde yer alan ve her iki disiplinin de temelini oluşturan bir kavram olduğunu söyleyen Ayyıldız ve Müştak, sinema için bir oyuncu kadar etkili sayılabilecek sinemasal mekânın, mimarlıkta insan yaşamını örgütleyen ve onu anlamlandıran bir unsur olduğundan bahsetmiştir. Diğer türlerden farklı olarak bilimkurgu sineması, mekân tasvirlerinin günümüzden radikal bir şekilde farklılaştığı unsurlara yer veren bir sinema türüdür (Ayyıldız ve Müştak, 2016, s. 1).

Her alanda teknolojinin kullanımıyla döneminin hep ötesinde araçların kullanıldığı bir tür olan bilimkurgu, insanoğlunun kendi potansiyellerinin farkına varıp, gündelik hayatında yapabileceği değişiklerle birlikte dünyaya müdahale edebilecek bir güç vermiştir (Topuz, 2013). Gelecekle ilgili düşüncelerin oluşması ve yeni fikirlerin inşası ve seyirciye aktarılması bağlamında bilimkurgu filmleri teknolojiyle sıkı bir ilişki içerisindedir.

\section{SINEMA VE MIMARLIK}

Sanat tarihi incelendiğinde birçok sanat disiplininin birbirinden etkilendiği ve birbiriyle iç içe olduğu görülür. Mimarlık ve sinema da birbirleriyle sürekli etkileşim içinde olan göstergeler aracılığıyla insanlarla iletişim kurabilen disiplinlerdir.

Şenyapılı, mimarlık ve sinema ilişkisinde sinemanın zaman ve mekân kullanımı konusunda mimarlığa göre daha özgür olduğunu, düşlediği mimari mekânları gerçekliğe dönüştürmekte daha geniş olanaklara sahip olduğunu söylemiştir. Sinema sanayisi için düş sanayisi yakıştırması yapıldığından bahsederek, sinemanın bir anlamda düşler üretmekte ve düşleri herkes için görünür kılmakta olduğuna değinmiş ve günümüzde ulaşılan teknolojinin bu sanayinin düş üretiminin sınırlarını olabildiğince genişlettiğinden bahsetmiştir (Şenyapılı,1998). Şenyapılı'nın söyleminden de yola çıkarak sinema ve mimarinin birbirini besleyen iki disiplin olduğunu, kimi zaman sinemadaki teknolojik gelişmelerin mimariye ilham olduğunu kimi zaman da mimari alandaki teknolojik gelişmelerin beyazperdede karşımıza çıktığını görürüz. 
açısı getirdiğini söyleyen Clarke, izleyicinin sinema aracılığı ile deneyimlediklerinin beklentilere dönüştüğünü söyler. Mimar, sinema ve mimarinin etkileşimi göz önünde bulundurulduğunda bu beklentileri karşılamakla yükümlüdür. Gelecekten bahseden filmler bu bağlamda mimarlar için bir ilham kaynağıdır (Clarke, 1997).

Geçmişe bakıldığında günlük kullanımda ki eşyalar ya da mekanlar şekillenirken iki ana kriter ağır basmaktaydı; Bir tanesi "kullanım amaçları", diğeri ise "estetik değerlerdi. Birinci kriter ele alındığında belirleyici olarak insanların intiyaçları ön planda tutuluyordu.,(Sogut,A., Aytar Sever,i., 2019)

İlk olarak mimarlar filmlerdeki mimari mekanlardan, özellikle ütopik ya da distopik filmlerdeki mekanlardan etkilenerek, bunları kendilerine referans almaktadır diyen Tükel, bunun sinemanın mimarlığa doğrudan bir etkisi olduğunu söylemektedir. (Tükel,2010: 21) Tükel'in ve Clarke'nin söylemlerini bu çalışma kapsamında değerlendirecek olursak özellikle gelecek teknolojilerinden fikirler veren bilim kurgu filmlerinde karşımıza çıkan teknolojik ögelerin zamanla günümüz iç mekân tasarımlarını etkilemesinin kaçınılmaz olduğunu söyleyebiliriz.

\section{TEKNOLOJI VE BILIM KURGU SINEMASI İLIŞKISi}

Teknoloji, etimolojik olarak Antik Yunancada zanaat ve eylem anlamına gelen "techne" sözcüğü ile söz ve bilgi anlamına gelen "logos" sözcüğünün birleşmesinden türetilmiştir (Kelly, 2010). Bir 'zanaat bilgisi' olarak teknoloji, bir anlamda insanın hayatta kalabilmek için tarih

boyunca ürettiği her şeydir. İnsanlık tarihinin başından itibaren üretilmiş en basit aletlerden başlayarak aynı soyutlama sürecine dayanan kavramlara kadar her şeyi kapsar (İnam, 2010).

Bilim kurgu filmlerinde teknoloji, çekildiği dönemin etkileriyle kurgulanan gelecek öngörüleridir. Bilim kurgu türünü diğer türlerden ayıran en önemli özelliği bilimsel tabanlı olması durumudur. Bilim ve teknoloji arasında, bilim geliştikçe beraberinde teknolojinin de geliştiği doğru orantılı bir ilişki söz konusudur. Teknolojinin devamlı gelişmesi sonucu, önceki dönemlerde kurgulanan bilim kurgu filmlerinin betimlediği geleceğin teknolojisinin ürünlerinin, sonraki dönemlerde ilkel olarak adlandırılmasına rağmen önemli olan filmlerin bilimsel verilere uygun bir anlatısı olmasıdır. Bu özelliği sonucunda teknoloji kavramının her dönem, bilim kurgu filmlerinin en önemli yapı taşlarından biri olduğu görülür (Küpeli İğdeli, 2013).

Bu bilgiler ışığında bilim kurgu filmlerinde teknolojik imgeler kurgulanırken aslında günümüzden ve yaşadığımız dünyadan esinlenerek gelecek teknolojilerinin tasarlandığı sonucuna varabiliriz. Teknoloji gelişerek bilim kurgu sinemasını şekillendirirken bilim kurgu sineması da gelecekle ilgili öngörüleriyle teknolojik gelişmeler için ilham kaynağı olur.

\section{YÖNTEM (METHOD)}

Bu çalışmada bilim kurgu filmleri üzerinden iç mekân bağlamında görülen akıllı teknolojilerin yansıtıldığı 4 adet film seçilerek incelenmiştir. Filmler seçilirken akıllı teknolojilerin iç mekâna yansıdığı filmler olması dikkate alınmıştır. Filmler izlenerek iç mekândaki yenilikçi teknolojiler belirlenmiş ve tablo haline getirilmiştir.

Filmlerde iç mekâna yansıyan teknolojik yenilikler bir gösterge niteliği taşıdığından yöntem olarak göstergebilimin ya da diğer adıyla semiyotik kullanılmıştır. 
Çağdaş göstergebilimin temellerini 20. Yüzyılın başlarında Amerikalı Charles Sanders Peirce ile birlikte oluşturan İsviçreli dilbilimci Ferdinand de Saussure, Genel Dilbilim Dersleri adlı eserinde göstergebilimi (semiology) göstergelerin toplumsal yaşam içindeki durumunu konu alan ve inceleyen bir bilim dalı olarak belirtmiştir (Saussure, 1998: 18). Gösterge bilimi anlamak için öncelikle gösterge kavramını bilmenin gerekliliğinden bahseden Çiçek, göstergelerin nitelik olarak her şeyin yerini alabildiğini, bu bakımdan da göstergenin her zaman kendi dışında başka bir şeyi gösteren bir nesne, olgu ya da varlık olduğundan bahsetmiştir. (Çiçek, 2008).

Gösterge kavramı ise dilsel ve görsel olarak ikiye ayrılmaktadır. Bu çalışma kapmasında bilim kurgu filmlerindeki teknolojik iç mekân ögeleri görsel olarak inceleneceği için görsel gösterge bilim yöntemi kullanılacaktır.

Pierce göre semiyotik analiz yapılırken gerekli olan üç parametre bulunmaktadır. Bunlar; Gösteren (Signifier), Gösterilen (Signfied) ve Yorumlama (Interpretation) 'dır (Echtner,1999). Gösteren, gösterilen ve yorumlamadan oluşan semiyotik üçgen (Şekil 1) bu çalışmaya uyarlanmıştır (Şekil 2).

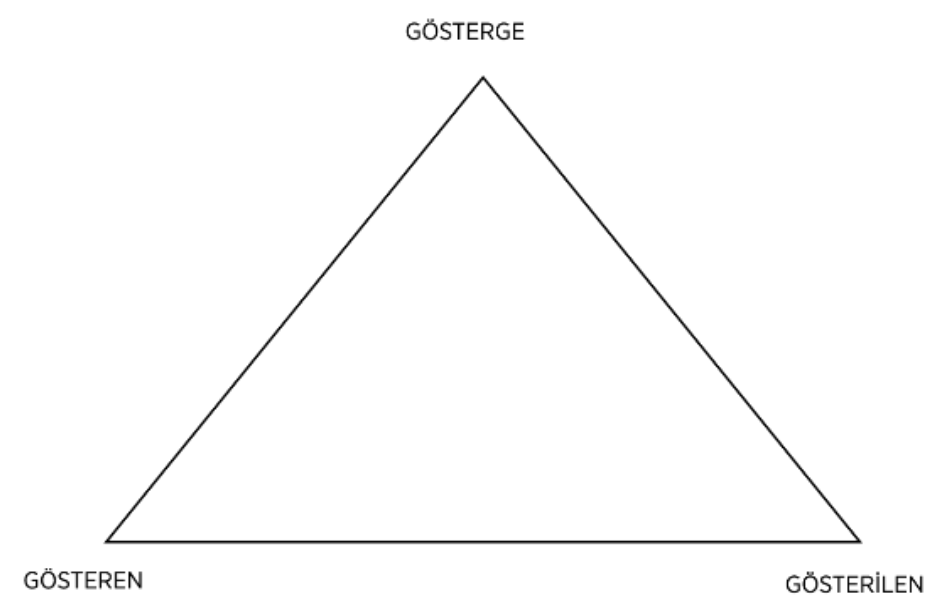

Şekil 1. Göstergebilimdeki en yaygın gösterge şeması, Kaynak: (Erkman, 1987)

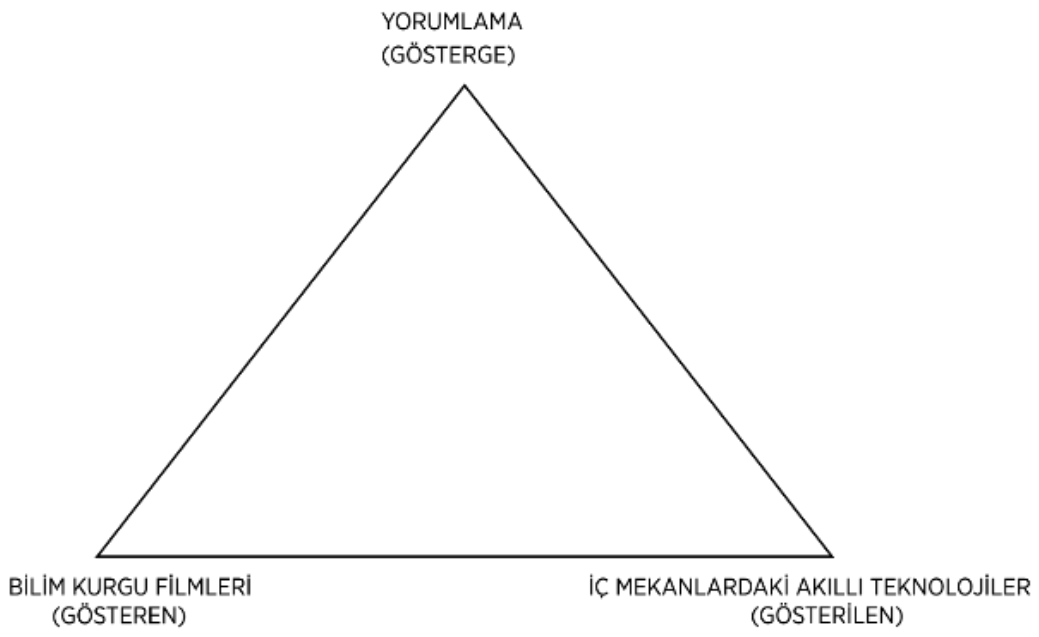

Şekil 2. Göstergebilim şemasının çalışmaya uyarlanması 
Şekillerde de görüldüğü gibi bu çalışma kapsamında bilim kurgu filmleri incelendiği için semiyotik üçgenin gösteren kısmında 'bilim kurgu filmleri' yer alırken, 'iç mekanlardaki akıllı teknolojiler' gösterilen kısmındadır. Filmlerin izlenip yorumlanmasıyla bazı bulgulara varılacağı için gösterge kısmında 'yorumlayıcı' bulunmaktadır.

\section{BULGULAR}

Bu kısımda Ferdinand de Saussure'nin temellerini attığı göstergebilimin semiyotik üçgeninden yararlanarak incelenen bilim kurgu filmlerinde iç mekânlardaki akıllı teknoloji unsurları belirlenmiştir. Gösterge niteliğindeki bu unsurlar yorumcu tarafından açıklanmıştır.

\subsection{METROPOLIS FILMININ INCELENMESI}

Metropolis filminde (gösteren); dijital ekranlar, uzaktan kontrol sağlayan mekanizmalar ve görüntülü konuşma yapabilmeyi sağlayan ögelere (gösterilen) rastlamaktayız. Gösterilen bu ögeler gelecekte iç mekânlarda kullanılacak akıllı teknolojiler için bir gösterge niteliği taşımaktadır (Tablo 1).

Tablo 1. Metropolis filminde iç mekânda akıllı teknoloji göstergelerinin saptanması

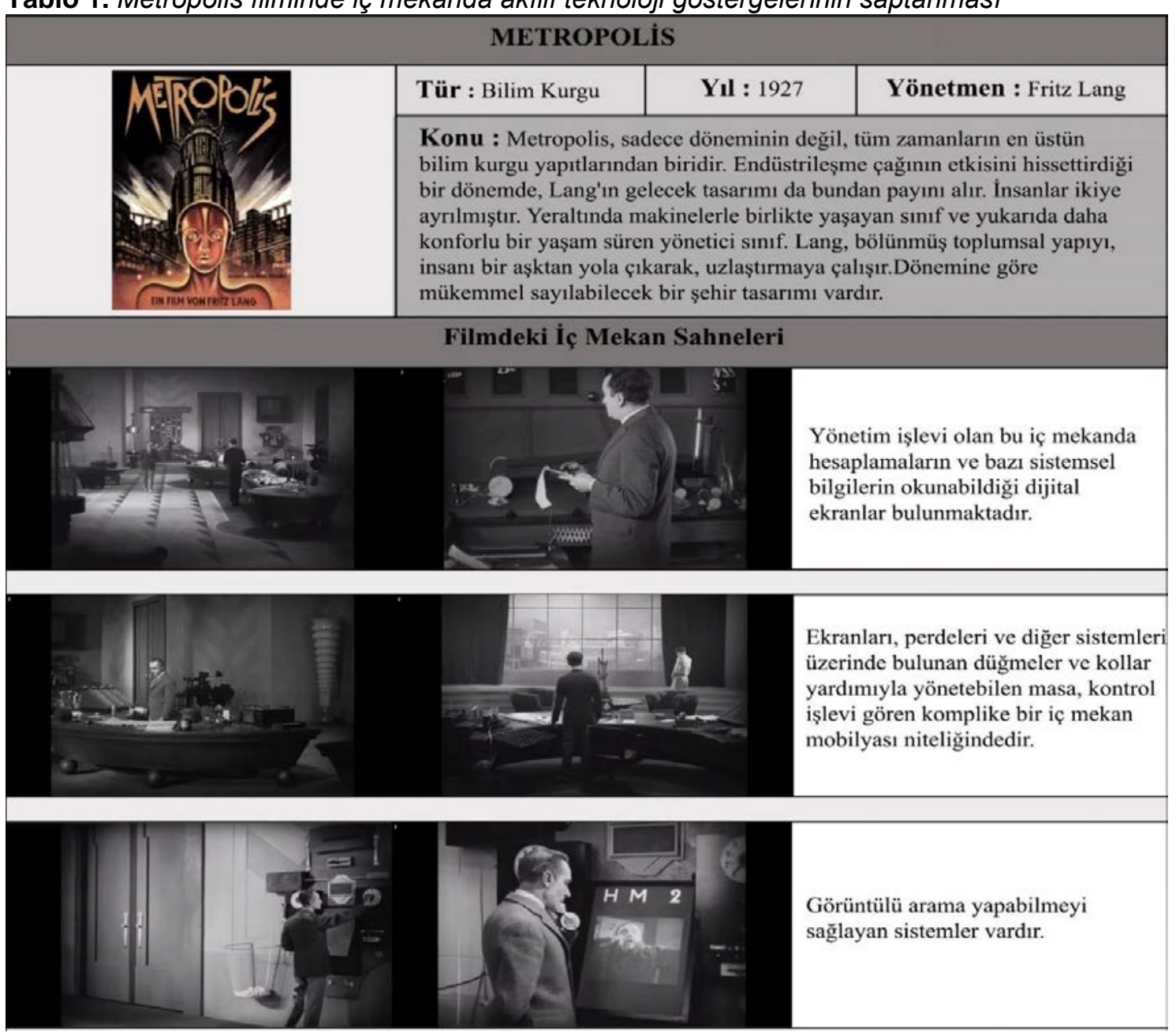




\subsection{CLOUD ATLAS (BULUT ATLASI) FILMININ INNCELENMESI}

Cloud Atlas filminde (gösteren); akıllı sistemlerle kontrol edilen ve mekânı oluşturan zemin, duvarlar, tavan gibi ögelerin (gösterilen) farklı form ve renklere dönüştüğünü, farklı işlevler aldığını görmekteyiz. Gösterilen bu ögeler gelecekteki iç mekân organizasyonlarının akıllı teknolojiler ile yönetilmesi açısından bir gösterge niteliği taşımaktadır (Tablo 2).

Tablo 2. Cloud Atlas filminde iç mekânda akıllı teknoloji göstergelerinin saptanması

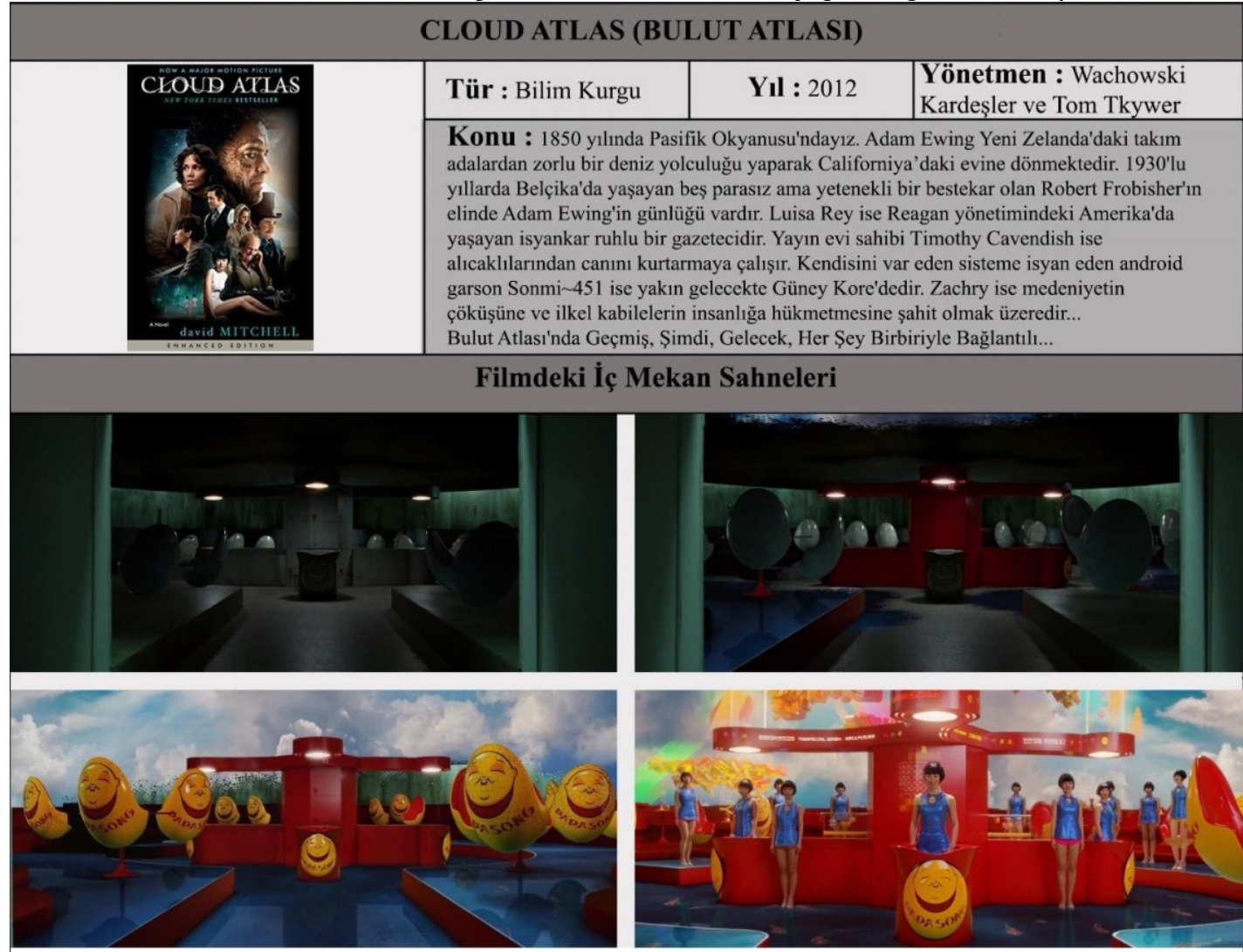

Akıllı sistemlerle yönetilen bu iç mekan sistemin çalıștııılmasıyla mekanik olarak açılan birimlerden oluşmaktadır. Mekanı oluşturan zemin, tavan, duvarlar ve oturma birimleri teknolojik bir biçimde form ve renk değiștirmektedir.
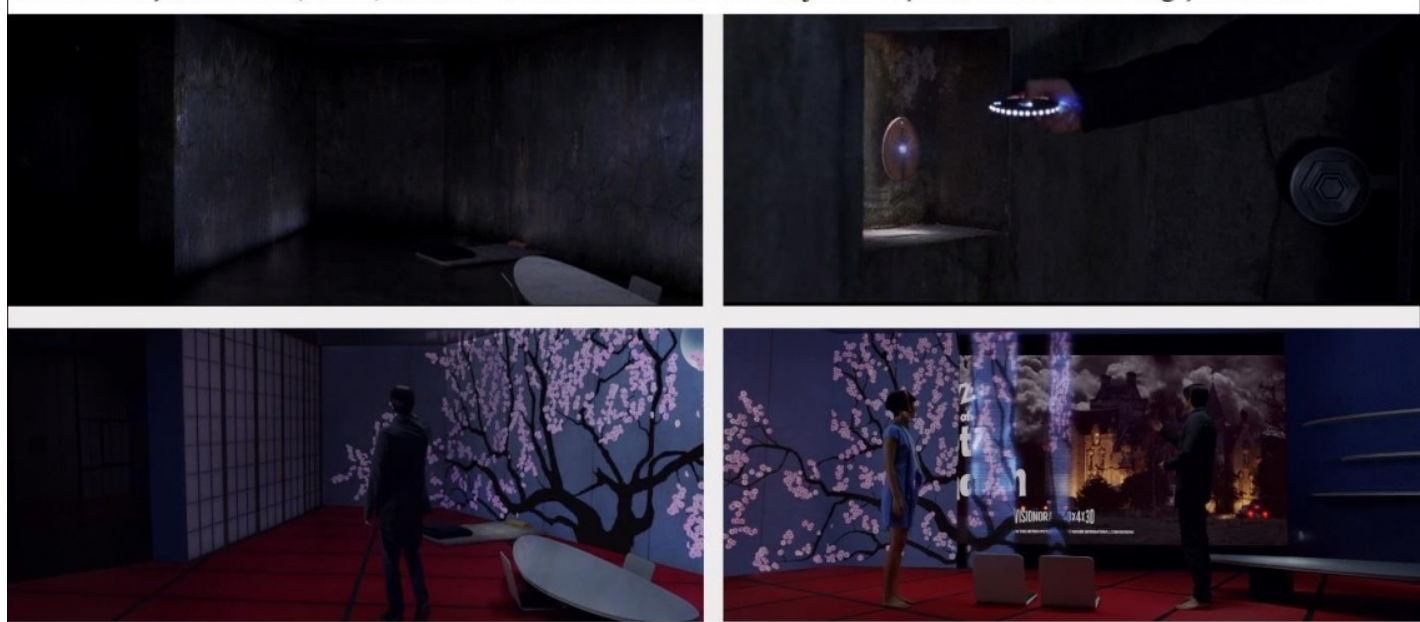

Mekanın girişinde bulunan bir panelin kumandalı bir sistemle çalıştırılması ile zemin, tavan ve duvarlar gibi mekanı oluşturan ögeler bazı form ve renk değişikleriyle yeni işlevlere hizmet etmektedir. Akıllı sistemler aracılığıyla duvarlar bir takım görüntülerin izlendiği ekranlara dönüşebilmektedir. 


\subsection{OBLIVION FILMININ INCELENMESI}

Oblivion filminde (gösteren); çeşitli fonksiyonları yöneten, görüntülü konuşmayı ve iletişimi sağlayan üzerinde kontrol panelleri bulunan bir ünite (gösterilen) vardır. Yaşam alanı olarak kullanılan bu iç mekânda aydınlatmayı sağlayan, kapı giriş çıkışını kontrol eden, spor aktivitelerindeki ölçümleri dijital olarak yapan akıllı sistemler (gösterilen) bulunmaktadır. Gösterilen bu ögeler gelecekte iç mekânlarda kullanılacak akıllı teknolojiler için bir gösterge niteliği taşımaktadır (Tablo 3).

Tablo 3. Oblivion filminde iç mekânda akıllı teknoloji göstergelerinin saptanması

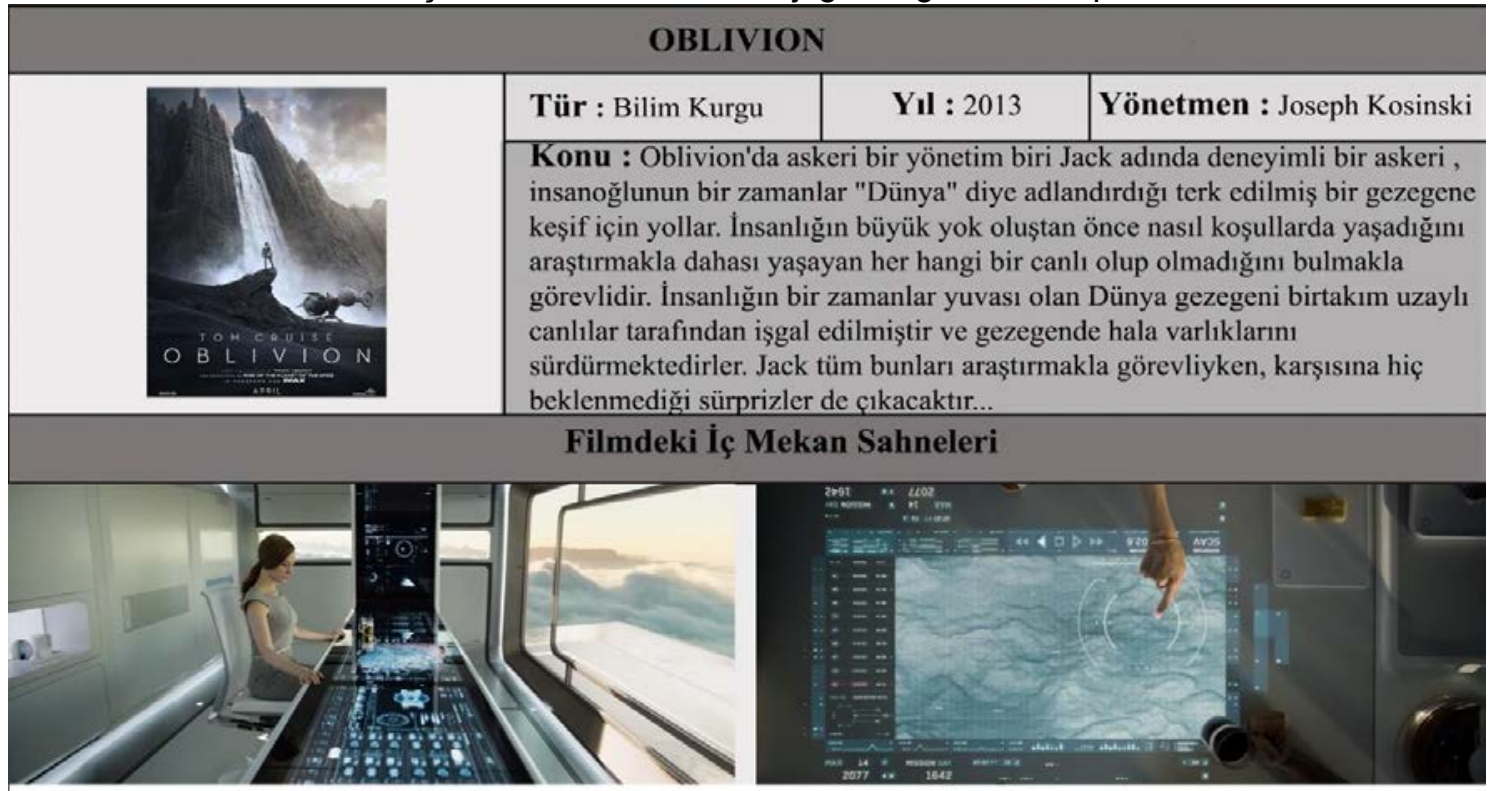

İç mekanda masa formuna entegre bir biçimde araç yönetimi, takibi, görüntülü konuşma gibi işlevleri karşılayan akıllı sistemlerin kullanıldığı bir ünite bulunmaktadır.
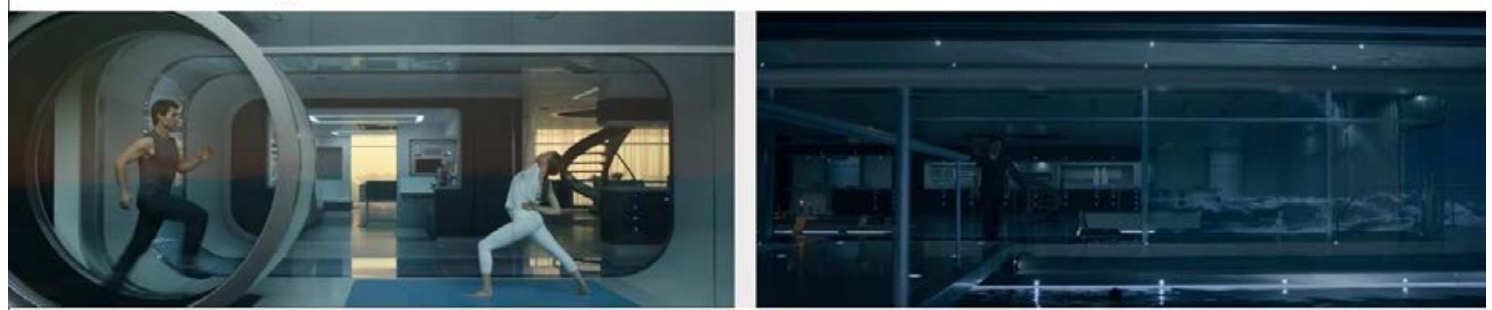

İnsan hareketlerini algılayan sensörleri sayesinde aydınlatma, spor faaliyetleri gibi fonksiyonları yöneten akıllı sistemler vardir. 


\subsection{UPGRADE FILMININ INNCELENMESI}

Upgrade filminde (gösteren); fiziksel engelli bir bireyin ihtiyaçlarını karşılamasını sağlayan akıllı sistemlerle tasarlanmış bir iç mekân görmekteyiz. Yiyecek içecek ve ilaç verme

gibi fonksiyonları sağlayan bir ünite (gösterilen) bulunmaktadır. Mekânın aydınlatması (gösterilen) akıllı sistemler sayesinde sağlanmaktadır. Duvar ve zemin gibi mekânı oluşturan ögelerde de akıllı sistemler tarafından yönetilen ve çeşitli işlevleri bulunan ekranlar (gösterilen) vardır. Gösterilen bu ögeler gelecekteki iç mekân tasarımlarının akılı teknolojiler ile yönetilmesi açısından bir gösterge niteliği taşımaktadır (Tablo 4).

Tablo 4. Upgrade filminde iç mekânda akıllı teknoloji göstergelerinin saptanması

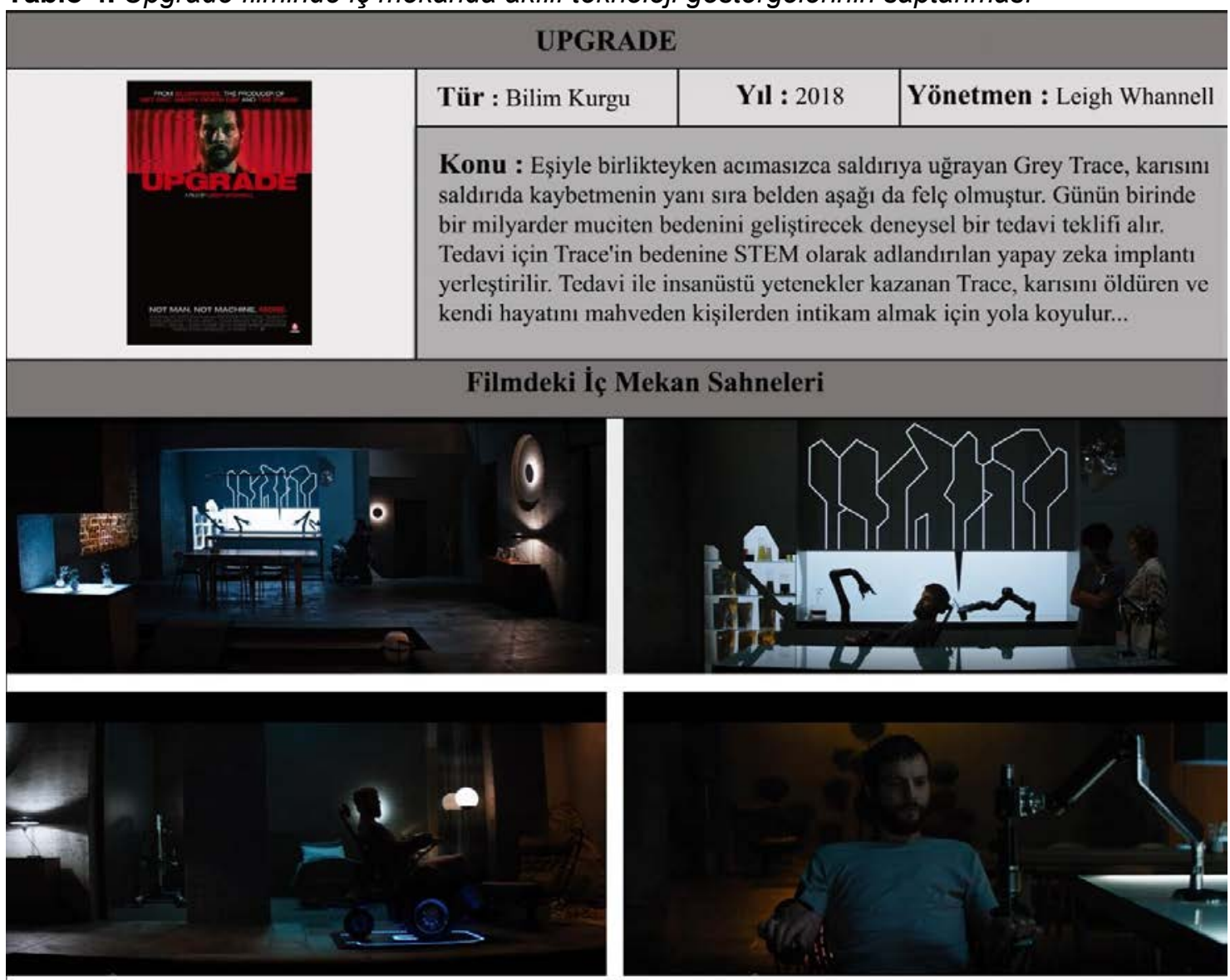

Fiziksel engelli bir birey için tasarlanmış bu iç mekanda, hareket yetisi olmayan bu bireyin yeme içme, ilaç alma gibi fiziyolojik ihtiyaçlarını karșılayan sesli olarak yönetilen akıllı sistemler bulunmaktadır. Aydınlatmalar akıllı sistemlerle yönetilmektedir, zeminde tekerlekli sandalyeyin şarj olmasını sağlayan bir tasarım var.

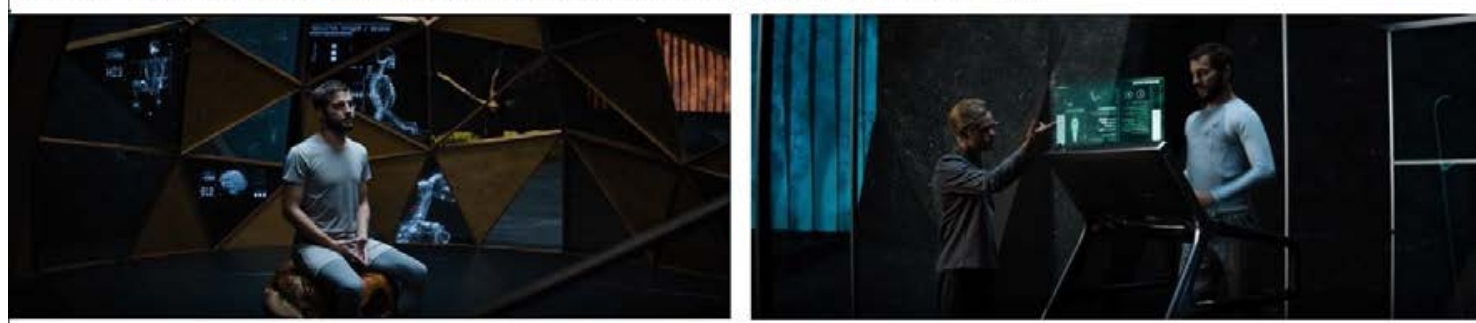

İnsan anatomisini algılayan ve bazı ölçümler yapan akıllı sistemler bulunmaktadır. Mekanda dijital duvar yüzeylerini oluşturan ekranlar bulunmaktadır. 


\section{SONUÇ}

Sinema ve mimarinin ortak kaygısı olan mekân tasarımı her geçen gün bu iki disiplinin birbiriyle daha sıkı ilişkiler kurmasını sağlamaktadır. Bu çalışmada bilim kurgu filmleri üzerinden iç mekânlardaki akıllı sistem teknolojileri incelenmiştir. İzlenen ve yorumlanan "Oblivion ve Metropolis" filmlerinde iç mekanlardaki akıllı teknolojiler; ekranlar, kontrol panelleri ve mobilya niteliği taşıyan bazı tasarımlar olarak karşımıza çıkmaktadır. Akıllı teknolojiler bu iki filmde karşımıza iç mekândaki bir obje ya da mobilya olarak çıkmaktadır. "Upgrade" filminde akılı teknolojiler sadece ürün odaklı olmaktan çıkarak mekânı oluşturan zemin, duvar, tavan gibi ögelerle mekânın oluşturan bir unsur haline gelmiştir. "Cloud Atlas" filminde ise iç mekânlar tamamen akıllı teknolojiler kontrolünde form, renk ve işlev olarak farklı biçimler alarak mekânın kendisini oluşturmaktadır.

Sonuç olarak izlenen ve yorumlanan filmlerde de görüldüğü gibi bilim kurgu sineması gelecekle ilgili fikirlerin oluşmasında ve bunların mimarideki iç mekân tasarımları için ilham kaynağı oluşturmasında oldukça etkilidir. Filmlerde önceden iç mekânda bir obje olarak görünen bu sistemler zamanla mekânın kendisini oluşturmaya başlamıştır. Bilim kurgu filmlerinde karşımıza çıkan ve iç mekânı oluşturan akılı teknolojilerin, olanakların da gelişmesiyle geleceğin iç mekân tasarımlarını oluşturması kaçınılmazdır.

\section{KAYNAKÇA}

Aytar Sever, I. ,Sogut A.,"Sandalyenin Endüstriyel Boyutu Ve Insan Üzerindeki Psikolojik Etkisi", Asoscongress Uluslararası Güzel Sanatlar Sempozyumu, Alanya 2019

Ayyıldız, S., Müştak, S.,"Sinema-Mimarlık Arakesitinde Cyberpunk (Siberpunk) ve "Ada" Filmi Üzerinden Eleştirel Bir Yaklaşım", Mimarlık ve Yaşam Dergisi, Cilt: 1, Sayı: 1, Kocaeli 2016 s.n.y

Beşışık, G., "Sinema ve Mimarlıkta Mekân Kurgusu ve Kavrayışı", Dokuz Eylül Üniversitesi Fen Bilimleri Enstitüsü, Yayınlanmış Yüksek Lisans Tezi, İzmir 2013 (s.n.y)

Clarke, D.B. , "The Cinematic City, Routledge”, New York 1997 (s.n.y)

Çiçek M., "Bazı Görsel Göstergelerin Yerel / Evrensel Karşıtığı Bağlamında Yorumlanması", XXII Ulusal Dil Bilimi Kurultayı Bildirileri içinde, Van 2008

Erkman, F., "Göstergebilime Giriş", Alan Yayıncılık, İstanbul 1997 (s.n.y)

Güntan, S.S., "Sinema Aracılığı ile Mimarlığın Sunumu: Wall Street - Borsa (1987) Filminin İncelenmesi", İstanbul Teknik Üniversitesi, Fen Bilimleri Enstitüsü Yayınlanmış Yüksek Lisans Tezi, İstanbul 2007 (s.n.y)

İnam, A., "Teknolojiye Ne Oldu?", Bibliotech, Sayı: 11, Nisan-Mayıs, s.16, Ankara 2010

Kevin, K., "What Technology Wants", Viking, s.6 ABD 2010

Küpeli İğdeli, B., "Mimarlık ve Bilim Kurgu Sineması Illişkisinin Ev Kavramı Üzerinden Irdelenmesi", Gazi Üniversitesi Fen Bilimleri Enstitüsü Yayınlanmış Yüksek Lisans Tezi, Ankara 2013 (s.n.y) 
Saussure F., (1998). Genel Dilbilim Dersleri, (Çev. Berke Vardar), Multilingual, İstanbul.(s.n.y)

Şenyapılı, Ö., (1998). Sinema ve Tasarım, ODTÜ Mimarlık Fakültesi Yayınları, Ankara.

Şenyapılı, Ö., (2002). Sinema ve Tasarım, Boyut Yayın Grubu, İstanbul. (s.n.y)

Tanyeli, U., (2001). Sinema ve Mimarlık: Temsiliyet Nesnenin Temsili Sanatın Sanallıkla İfadesi, Arredamento Mimarlık, 141, 66.

Topuz, Ö. (2013). Bilim kurgu Filmlerinin Mimari Açıdan Gelecekle Illgili Fikirlerin Oluşmasına Katkısı, İstanbul Teknik Üniversitesi, Fen Bilimleri Enstitüsü Yayınlanmış Yüksek Lisans Tezi, İstanbul.(s.n.y)

Tükel, G., (2010). Edebi Eserlerde Sinemada Betimlenmiş Mimari Mekanların Sinemada Temsili, İstanbul Teknik Üniversitesi, Fen Bilimleri Enstitüsü Yayınlanmış Yüksek Lisans Tezi, İstanbul.(s.n.y) 